\title{
Short Communication: The mitochondrial cytochrome c oxidase subunit I (COI) for identification of batoids collected from landed sites in Medan, Indonesia
}

\author{
MUFTI SUDIBYO $^{1}$, KHAIRIZA LUBIS ${ }^{1, \boldsymbol{v}}$, ACHMAD FARAJALLAH ${ }^{2}$, NISFA HANIM ${ }^{2}$ \\ ${ }^{1}$ Department of Biology, Faculty of Mathematics and Natural Sciences, Universitas Negeri Medan. J1. Willem Iskandar Pasar V, Medan 20221, North \\ Sumatra, Indonesia. Tel.: +62-66-14002, Fax.: +62-66-13319, `email: khairizalubis@unimed.ac.id, khairizalubis15@gmail.com. \\ ${ }^{2}$ Departement of Biology, Faculty of Mathematics and Natural Sciences, Institut Pertanian Bogor. Jl. Meranti, Kampus IPB Darmaga, Bogor 16680, West \\ Java, Indonesia
}

Manuscript received: 5 June 2020. Revision accepted: 26 October 2020.

\begin{abstract}
Lubis K, Sudibyo M, Farajallah A, Hanim N. 2020. Short Communication: The mitochondrial cytochrome c oxidase subunit I (COI) for identification of batoids collected from landing sites in Medan, Indonesia. Biodiversitas 21: 5414-5421. Batoids are member of Elsamoranch subclass which consist of many species. Most of batoids species are overexploited, especially in Medan Indonesia. Up to presents, the information about diversity of rays on the east coast of North Sumatra, Indonesia was very limited. Therefore, this research aimed to investigate the diversity of rays on the east coast of North Sumatra. We examined the morphological trait of 82 individuals of batoid from three landing sites on the east coast of North Sumatra, namely: Tanjung Balai, Belawan, and Percut, then identify its species based on determination key. After that, we collected pectoral muscle tissue from an individual in each species which successfully identified to extract its genomic DNA. Molecular based identification was carried out by using DNA fragment form COI gene. The successfully amplificated COI gene DNA fragment then was sequenced and analyzed. Based on morphological trait, we successfully identifying nine species of batoid, which is Maculabatis gerrardi, Gymnura poecilura, Dasyatis zugei, Brevitrygon heterura, Neotrygon kuhlii, Hemitrygon bennettii, Rhinobatos jimbaranensis, Rhinoptera javanica, and Taeniura lymma. The result of identification based on COI gene DNA fragment was in congruent with morphological-based identification based on data BLAST-N and genetic distance value within same species. The nucleotide diversity within same species ranged from 0-15 nucleotide variants.
\end{abstract}

Keywords: $C O I$ gene, rays, Medan, Indonesia

\section{INTRODUCTION}

Indonesian marine waters is known as having the richest diversity of Elasmobranch fishes and also as the center of diversity in the world. Several studies on Elasmobranch diversity had been conducted. A total of 207 species from 44 families of Chondrichthyans were found in Indonesian marine waters, which consist of 109 sharks, 96 batoids, and two ghost sharks (chimeras) (Fahmi 2010). Another study reported that at least 221 species of sharks and batoids found in Indonesian marine waters (Sadili et al. 2015). Recently, a study of Elasmobranch in the North Sumatra reported that eight species of sharks and batoids were caught and landed in Belawan and Batubara (Fadhilah et al. 2019).

Batoid is one of member of Elasmobrach subclass and closely related to sharks. This group consists of fishes that had moderately to greatly flattened body (dorsoventrally), ventral gill slit, enlarged pectoral fin, lack of anal fin, and its enlarged pectoral fin were fused to the side of the head and snout (Compagno 1999; McEachran and de Calvarho 2002). The body and conjoined of head enlarged pectoral fin and snout forming a disc, that delimited from its tail (Compagno 1999; McEachran and de Calvarho 2002). Batoid disk's shape was varied there are wedge-shape, circular, oval, and rhomboidal (Compagno 1999). Besides its shape, the size (length) of this group were varied, from $100 \mathrm{~mm}$ to more than $7000 \mathrm{~mm}$ (Compagno 1999). As of 7 November 2015, the number of batoid species in the world which has been reported was 630 species (Wiegmann 2016). Several species of batoid had been going through taxonomic review, due to new feature (morphology or molecular) were found, i.e. Himantura gerrardi, Dasyatis bennetti, Himantura walga had been under toxonomic review and now were called Maculabatis gerrardi, Brevitrygon walga and Hemitrygon bennettii, respectively (Last et al 2016; Froese and Pauly 2020).

Morphology-based identification methods were used to identifying species of certain organisms based on morphological features. This identification process was done by comparing the morphological features of sample with morphological features description in the determination key. While this method were of the fastest and cheapest approach, there is certain circumtances that we need to collect or exploit more biological data to successfully identify species of sample, such as specimen species that has similar morphological trait with other species from the same genus, cryptic species, immature specimen, incomplete specimen and hybrid species (Dudgeon et al. 2012). In this circumtances DNA-based identification were solution to collect or exploit more biological data from specimen. DNA-based identification 
method or DNA barcoding is a method that used standardized DNA fragment sequence to identify species of an organism interest (Hebert et al. 2003a). The mitochondrial genome is accumulating high percentage of neutral mutations that can be helpful in species identification (Siddappa et al. 2013). Up to present, there is several DNA marker from mitochondrial DNA that was known can be used in DNA barcoding of fish, one of them is DNA fragmen from COI gene (Dudgeon et al. 2012). Due to commonly used as DNA marker in DNA barcoding (Dudgeon et al. 2012), the amount of data about COI gene in GenBank was huge (11680 data for shark and batoids) so we used DNA fragment from COI gene for this study.

Batoid fishes was known have high economic value such as it skin used for basic materials of shoes, begs and belts and also it oil, teeth and bones can also be used for medicinal ingredients and glue (Subrata et al. 2017). Based on fisherman explanation, batoid were popular good for expor (personal communication). Due to that, nowadays, batoid were overexploited (Sadili et al. 2015). While the situation is like that, up to present the information about batoid in Indonesia were limited especially molecular information. In North Sumatra the information about batoid that available is about diversity of batoid that inhabit marine water in there (Puteri et al. 2017; Fadhilah et al. 2019). Herein, the present study is devoted to species identification and diversity of batoids in the east coast of North Sumatra, Indonesia based on mitochondrial cytochrome c oxidase subunit I (COI) gene.

\section{MATERIALS AND METHODS}

\section{Flesh sample collection and morphological identification}

The present study was conducted from September 2019 to October 2019. A total of 82 individuals of batoid fishes, which caught by local fishermens in Malaka Strait area, at 3 landing site in the east coast of North Sumatra, namely Belawan, Tanjung Balai and Percut (Figure 1) were examined for its morphological features and were identified for its species based on White et al (2006). Small part of pectoral fin muscle tissue under the skin from one individual from each species, which has successfully identified, were collected. The muscle tissue sample, then, were placed in $15 \mathrm{~mL}$ tube, after that alcohol $96 \%$ were added until muscle tissue submerged.

Table 1. Reference DNA sequence of COI gene of batoids

\begin{tabular}{ll}
\hline Species & Accession number \\
\hline Brevitrygon heterura & MG792099 \\
Dasyatis zugei & EU398759 \\
Dasyatis bennettii & KF604910 \\
Himantura gerrardi & MH230945 \\
Neotrygon kuhlii & KU497951 \\
Taeniura lymma & KM881715 \\
Gymnura poecilura & EU398804 \\
Rhinoptera javanica & JF494383 \\
Rhinobatos jimbaranensis & EU398994 \\
\hline
\end{tabular}

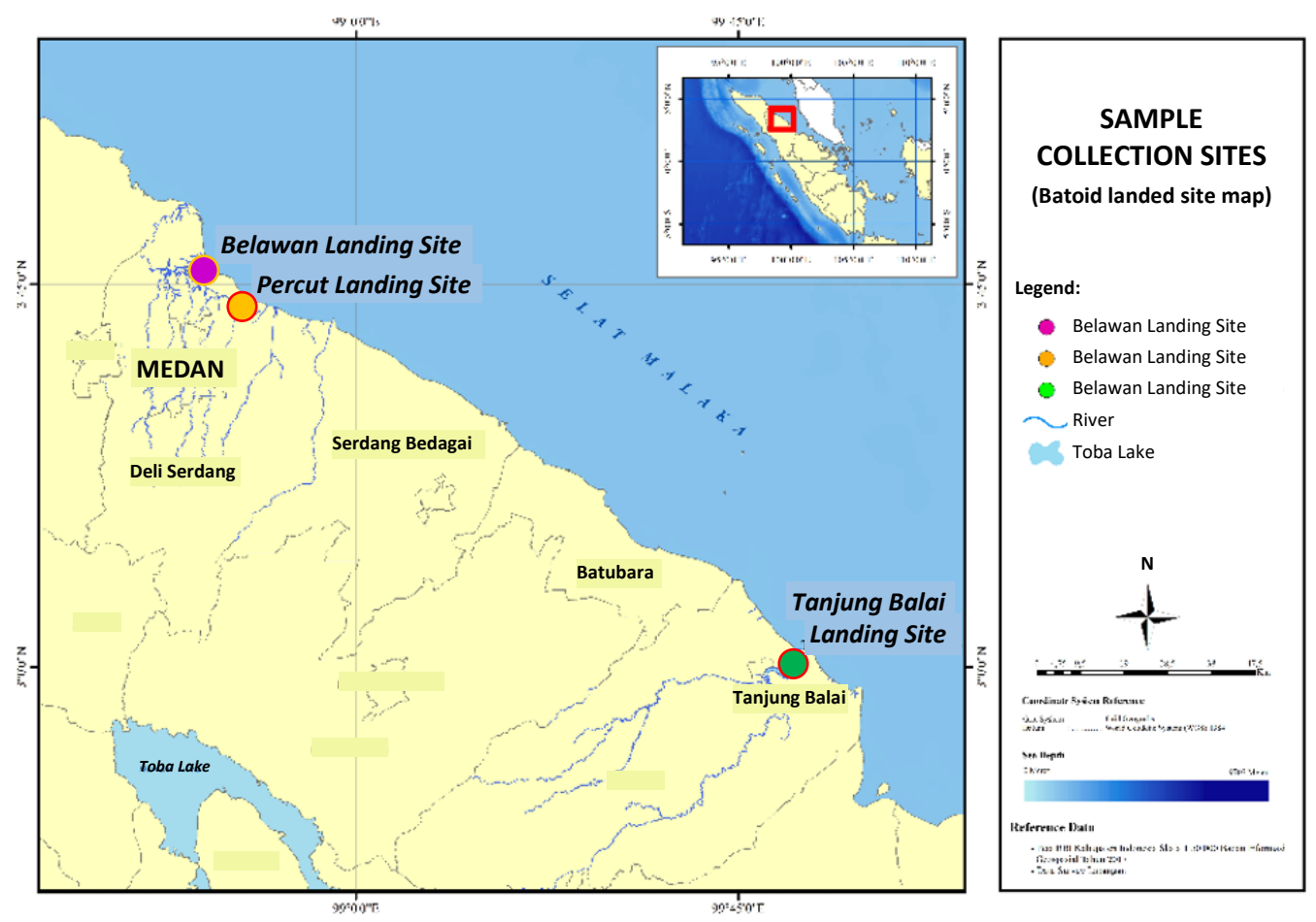

Figure 1. Map of three landed sites of batoids in east Sumatra coast of North Sumatra Province, Indonesia; purple circle is Belawan landing site, orange circle is Percut landing site and green circle is Tanjung Balai landing site 


\section{Genomic DNA extraction}

Small parts from preserved samples were cut with a sterile surgical scissor, put in the $1.5 \mathrm{~mL}$ tube, then soaked in sterile water to remove the preserving liquid for 20-30 minutes. After that, the tubes containing small parts of sample were centrifuged $5000 \mathrm{rpm}$ for 1 minute then the sterile water was removed. The tissue samples were cut to fine pieces in the tubes with a sterile surgical scissor. Then, genomic DNA extraction was carried out using DNA GENEAID Genomic DNA Mini Kit (Tissue) (Geneaid, Canada) and were done according to the protocol of the manufacturer.

\section{Polymerase Chain Reaction (PCR) and Sequencing}

The mitochondrial COI gene was amplified by polymerase chain reaction (PCR) method using the forward primer AF585 5'-ACCAACCACAAAGACATTGGCAC and the reverse primer AF586 5'-ACTTCTGGGTGGCCAAAG AATCA, which was modified from primer C_FishF1t1 5'TGTAAAACGACGGCCAGTCGACTAATCATAAAGA TATCGGCAC and C_FishR1t1 5'-CAGGAAACAGCTAT GACACCTCAGGGTGTCCGAARAAYCARAA Ward et al. 2005). Amplification of COI gene fragment was conducted by using GoTaq Green Mastermix ${ }^{\circledR}$ DNA Polymerase (Promega) with the following steps: predenaturation for 3 minutes at $95^{\circ} \mathrm{C}$, followed by denaturation, 30 cycles at $95{ }^{\circ} \mathrm{C}$ for 1 minute, annealing for 15 seconds at $52^{\circ} \mathrm{C}$, and an extension for 10 minutes at $72^{\circ} \mathrm{C}$. All products of PCR were separated using polyacrylamide gel electrophoresis and stained using silver staining method (Byun et al. 2009). These products of PCR were sent to $1^{\text {st }}$ Base for DNA sequencing.

\section{Molecular identification and species diversity analysis}

The DNA sequencing products were displayed and edited using BioEdit 7.0.9.0 software (Hall 1999) and followed by aligning sequence from primer forward and reverse from the same sample using ClustalW which embedded in MEGA7 software (Kumar et al. 2016). After that, we combined/contig the two sequences to produce the COI gene DNA sequence that was ready to be analyzed further. To identify its species, firstly similarity analysis was conducted, using the GenBank BLAST-N program (Altschul et al. 1990) to compare COI gene DNA fragments from each sample with other mitochondrial DNA fragments in database. After we get the BLAST-N result, the top one sequence was downloaded and used as reference sequence (Table 1), then we aligned all COI gene DNA sequence from all sample with it using ClustalW which embedded in MEGA7 software using then we conduct genetic distance analysis with p-distance method to further identifying species of each sequence. Besides that, we also conducting nucleotide variation and construct phylogenetic tree. The phylogenetic tree was constructed using Neighbour-Joining for statistical methods (Saitou and
Nei 1987)with Kimura 2-Parameter for subtitution model (Kimura 1980) and bootstrap method for test of phylogeny (Felsenstein 1985) with number of bootstraps was 1000. Neighbor-Joining method with nucleotide substitution model Kimura 2-parameter was used due to this option was the most used option to analyze the diversity pattern of $\mathrm{COI}$ gene (Hajibabei et al. 2006; Puillandre 2009)

\section{RESULTS AND DISCUSSION}

\section{Results}

Eighty-two batoids, which were examined its morphological features directly in the three landing sites, were successfully identified belonged to 2 ordo, 4 family, and 9 species (Table 2). Morphological features of the 9 species of batoid were presented in Table 3. Species diversity that we found in this study were different from the previous study of Fadhilah et al. (2019) which also took place in North Sumatra, around Malaka Strait. Fadhilah et al. (2019) only found 6 species of batoid while we found nine ( 3 species more). Only two species of batoid that were found both in this study and Fadhilah et al. (2019) that is $T$. lymna and $N$. kuhlii, while the other seven species were only found in this study. Brevitrygon heterura was batoid species with the most numbered individual which we found in these three landing sites (Belawan, Percut, and Tanjung Balai) and this species had different size of disc width (DW) and tail length (CL) with B. walga (B.heterura was species of $B$. walga that inhabit in Indonesian marine water) that was described by Simpfendorfer et al. (2017). The size of disc width (DW) and tail length (CL) of this species in our study are $17.14 \pm 1.92 \mathrm{~cm}$ and $21.36 \pm 4.87$ respectively, while in Simpfendorfer et al. (2017) is 23-32 $\mathrm{cm}$ and 23-50.6 cm (1-2.2 times DW) respectively. We also found 1 individual of Rhinobatos jimbaranensis, which were previously reported by Last et al. (2006) as endemic species in Jimbaran Bay (Southern Bali).

Table 2. List of successfully identified batoid fishes and individual frequency of each species which found in three landed site

\begin{tabular}{lll}
\hline $\begin{array}{c}\text { Order } \\
\text { Family }\end{array}$ & Species & $\begin{array}{c}\text { Number of } \\
\text { individuals }\end{array}$ \\
\hline Myliobatiformes & & \\
Dasyatidae & Brevitrygon heterura & 28 \\
& $\begin{array}{l}\text { Dasyatis zugei } \\
\text { Hemitrygon bennettii }\end{array}$ & 6 \\
& Maculabatis gerrardi & 8 \\
& Neotrygon kuhlii & 16 \\
& Taeniura lymma & 6 \\
Gymnuridae & Gymnura poecilura & 2 \\
Myliobatidae & Rhinoptera javanica & 11 \\
Rajiformes & & \\
Rhinobatidae & Rhinobatos jimbaranensis & 1 \\
\hline
\end{tabular}


Table 3. Morphological features of nine batoid species

\begin{tabular}{|c|c|c|c|c|c|c|}
\hline \multirow{2}{*}{ Species } & \multirow{2}{*}{ Qualitative morphological features } & \multicolumn{5}{|c|}{ Quantitative morphological features } \\
\hline & & $\mathbf{W}(\mathrm{g})$ & TL $(\mathbf{c m})$ & CL $(\mathbf{c m})$ & DL (cm) & DW (cm) \\
\hline Brevitrygon heterura & $\begin{array}{l}\text { No skin fold on ventral surface of tail } \\
\text { Profile of disc somewhat oval } \\
\text { Tail short, not whip-like (end bulbous in adult females) } \\
\text { Tail thorns very elongate, bases nearly half eye diameter in length } \\
\text { Mid-disc thorns absent or rudimentary }\end{array}$ & $187.86 \pm 83.64$ & $36.61 \pm 5.72$ & $21.36 \pm 4.87$ & $18.55 \pm 2.29$ & $17.14 \pm 1.92$ \\
\hline Dasyatis zugei & $\begin{array}{l}\text { Low skin fold present on ventral surface of tail } \\
\text { Tail not banded posterior to sting } \\
\text { Snout extremely elongate } \\
\text { Anterior margin of disc distinctly concave } \\
\text { No oral papillae }\end{array}$ & $255.00 \pm 220.43$ & $46.33 \pm 12.74$ & $27.17 \pm 7.39$ & $21.83 \pm 5.67$ & $19.25 \pm 4.12$ \\
\hline Hemitrygon bennettii & $\begin{array}{l}\text { Skinfold present on ventral surface of tail } \\
\text { The hind of tail to sting is not striped } \\
\text { Very long tail } \\
\text { Very small eyes } \\
\text { Enlarged thorns were found on the middle of disk and along the tail } \\
\text { Whip-like tail } \\
\text { There are small denticles skin in the middle of dorsal } \\
\text { Tail is covered by small thorn }\end{array}$ & $460.00 \pm 278.23$ & $50.48 \pm 8.49$ & $31.16 \pm 5.46$ & $20.31 \pm 4.63$ & $25.06 \pm 4.20$ \\
\hline Maculabatis gerrardi & $\begin{array}{l}\text { No skin fold on ventral surface of tail } \\
\text { Profile of disc quadrangular } \\
\text { Tail whip-like, with alternating light and dark bands } \\
\text { Upper surface greyish brown with numerous white spots, variably } \\
\text { distributed over disc (from almost plain to fully spotted) }\end{array}$ & $375 \pm 150$ & $79 \pm 6.78$ & $62 \pm 7.79$ & $20.3 \pm 1.71$ & $21.4 \pm 2.18$ \\
\hline Neotrygon kuhlii & $\begin{array}{l}\text { Low skin fold present on ventral surface of tail } \\
\text { Low skin fold on dorsal tail beyond sting } \\
\text { Tail with broad black and white bands, not whip-like } \\
\text { Snout short with black bar through eyes } \\
\text { Large, bright, blue spots on upper disc } \\
\text { Usually no thorns on tail before sting }\end{array}$ & $460.00 \pm 278.23$ & $50.48 \pm 8.49$ & $31.16 \pm 5.46$ & $20.31 \pm 4.63$ & $25.06 \pm 4.20$ \\
\hline Taeniura lymma & $\begin{array}{l}\text { Ventral skin fold on tail moderately deep, extending to tail tip } \\
\text { Profile of disc oval } \\
\text { Upper surface with bright blue spots } \\
\text { Stings present (usually 2), located near end of tail } \\
\text { Tail with a long blue stripe extending alongside before sting }\end{array}$ & $655.0 \pm 68.63$ & $61.2 \pm 3.25$ & $37.7 \pm 2.34$ & $27.0 \pm 2.28$ & $43.09 \pm 3.14$ \\
\hline Gymnura poecilura & $\begin{array}{l}\text { Dorsal fin absent } \\
\text { Tail lacking a sting, and with } \sim 9 \text { dark bands } \\
\text { Dorsal surface usually plain, sometimes with faint pale spots }\end{array}$ & 720 & 39 & 1845 & 24 & 45 \\
\hline Rhinoptera javanica & $\begin{array}{l}\text { The snout strongly notched medially to form two lobes } \\
\text { The tail is short } \\
\text { The head is rather wide }\end{array}$ & $1.315 .45 \pm 314.69$ & $66.18 \pm 6.52$ & $40.45 \pm 5.37$ & $30.27 \pm 2.83$ & $43.09 \pm 3.14$ \\
\hline Rhinobatos jimbaranensis & $\begin{array}{l}\text { Have dark spots on dorsal area, not white spot } \\
\text { Lower lobe of the tail is short } \\
\text { Denticles along the midline of dorsal area are not clear } \\
\text { Slightly large nostril }\end{array}$ & 1300 & 77 & 43 & 40 & 24 \\
\hline
\end{tabular}

Note: W: weight; TL: Total Lenght; CL: Tail Lenght; DL: Disc Length; DW: Disc Width; g: gram; cm: centimeter. 
Table 5. Genetic distance of $\mathrm{COI}$ gene fragment between nine batoid species

\begin{tabular}{|c|c|c|c|c|c|c|c|c|c|c|c|c|c|c|c|c|c|c|}
\hline & 1 & 2 & 3 & 4 & 5 & 6 & 7 & 8 & 9 & 10 & 11 & 12 & 13 & 14 & 15 & 16 & 17 & 18 \\
\hline 1 & & & & & & & & & & & & & & & & & & \\
\hline 2 & 0.201 & & & & & & & & & & & & & & & & & \\
\hline 3 & 0.182 & 0.134 & & & & & & & & & & & & & & & & \\
\hline 4 & 0.146 & 0.191 & 0.174 & & & & & & & & & & & & & & & \\
\hline 5 & 0.168 & 0.166 & 0.157 & 0.177 & & & & & & & & & & & & & & \\
\hline 6 & 0.190 & 0.163 & 0.149 & 0.180 & 0.128 & & & & & & & & & & & & & \\
\hline 7 & 0.199 & 0.199 & 0.207 & 0.187 & 0.188 & 0.184 & & & & & & & & & & & & \\
\hline 8 & 0.179 & 0.191 & 0.184 & 0.161 & 0.165 & 0.172 & 0.212 & & & & & & & & & & & \\
\hline 9 & 0.199 & 0.203 & 0.207 & 0.176 & 0.203 & 0.204 & 0.223 & 0.204 & & & & & & & & & & \\
\hline 10 & $0.000^{*}$ & 0.201 & 0.182 & 0.146 & 0.168 & 0.190 & 0.199 & 0.179 & 0.199 & & & & & & & & & \\
\hline 11 & 0.204 & $0.003 *$ & 0.134 & 0.195 & 0.169 & 0.166 & 0.203 & 0.191 & 0.206 & 0.204 & & & & & & & & \\
\hline 12 & 0.184 & 0.136 & $0.002 *$ & 0.176 & 0.158 & 0.149 & 0.209 & 0.185 & 0.209 & 0.184 & 0.136 & & & & & & & \\
\hline 13 & 0.142 & 0.193 & 0.176 & $0.003 *$ & 0.176 & 0.180 & 0.188 & 0.161 & 0.177 & 0.142 & 0.196 & 0.177 & & & & & & \\
\hline 14 & 0.166 & 0.168 & 0.158 & 0.176 & $0.002 *$ & 0.127 & 0.190 & 0.163 & 0.201 & 0.166 & 0.171 & 0.160 & 0.174 & & & & & \\
\hline 15 & 0.185 & 0.163 & 0.152 & 0.176 & 0.128 & $0.006^{*}$ & 0.179 & 0.171 & 0.206 & 0.185 & 0.166 & 0.152 & 0.176 & 0.127 & & & & \\
\hline 16 & 0.199 & 0.199 & 0.207 & 0.187 & 0.188 & 0.184 & $0.000^{*}$ & 0.212 & 0.223 & 0.199 & 0.203 & 0.209 & 0.188 & 0.190 & 0.179 & & & \\
\hline 17 & 0.185 & 0.191 & 0.180 & 0.168 & 0.168 & 0.166 & 0.210 & $0.006 *$ & 0.207 & 0.185 & 0.191 & 0.182 & 0.168 & 0.166 & 0.165 & 0.210 & & \\
\hline 18 & 0.207 & 0.204 & 0.198 & 0.182 & 0.206 & 0.201 & 0.222 & 0.195 & $0.024 *$ & 0.207 & 0.207 & 0.199 & 0.184 & 0.207 & 0.203 & 0.222 & 0.198 & \\
\hline
\end{tabular}

Note: *: genetic distance between same species; 1. B. heterura; 2. D. zugei; 3. Hemitrygon bennettii; 4. M. gerrardi; 5. N. kuhlii; 6. T. lymma; 7. G. poecilura; 8. Rhinoptera javanica; 9 . Rhinobatos jimbaranensis; 10. MG792099 B. heterura; 11. EU398759 D. zugei; 12. KF604910 D. bennetti; 13. MH230945 Himantura gerrardi; 14. KU497951 N. kuhlii; 15. KM881715 T. lymma; 16. EU398804 G. poecilura; 17. MG792069 Rhinoptera javanica; 18. EU398994 Rhinobatos jimbaranensis 


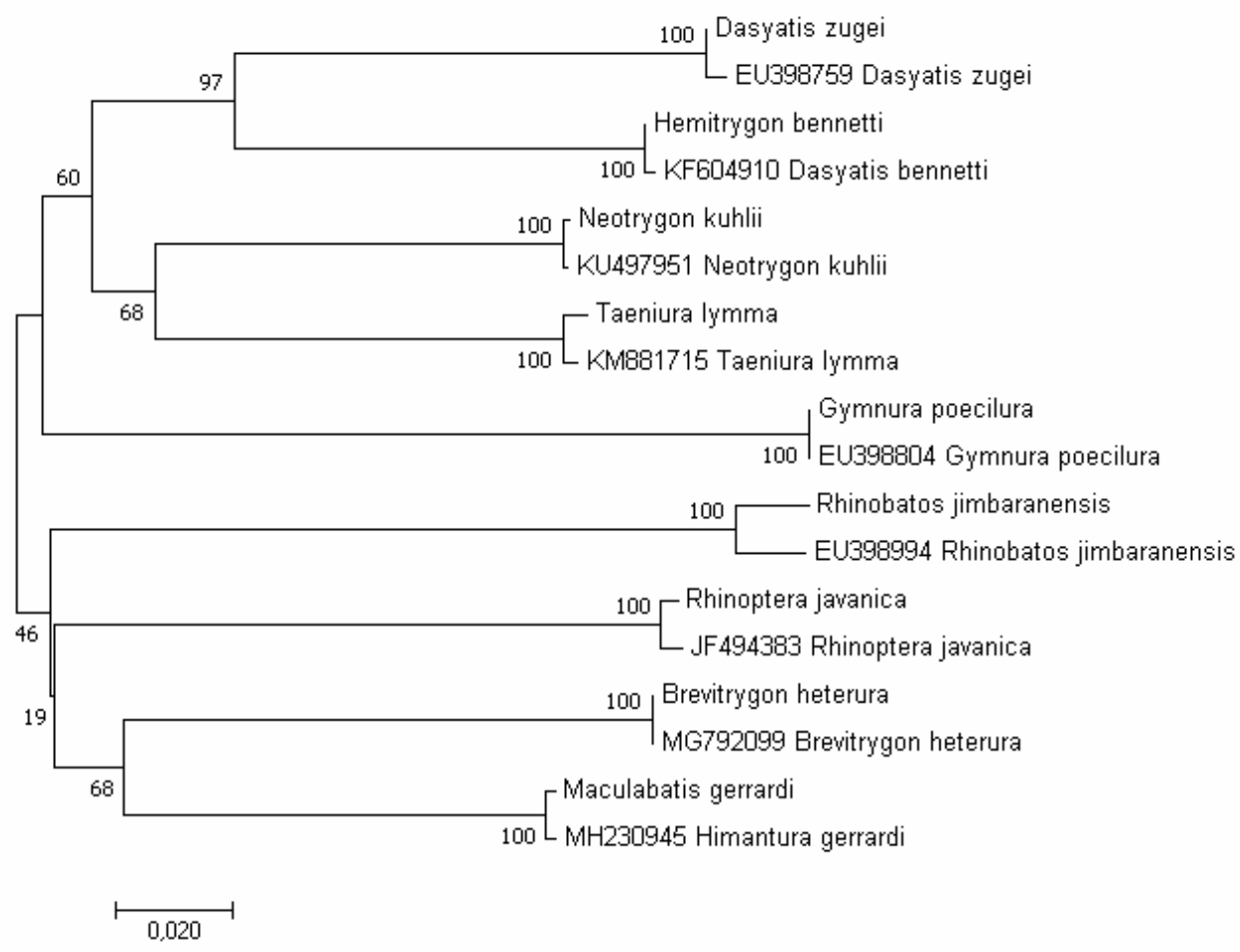

Figure 2. Phylogenetic tree of nine batoid species which found in three landed site based on COI gene fragment constructed using Neighbour-joining method with Kimura 2-Parameter model and 1000 bootstrap

Table 4. BLAST-N result of nine batoid species which found in three landed site

\begin{tabular}{llllll}
\hline Organism species of sample sequence & $\begin{array}{l}\text { Organism species of reference } \\
\text { sequence }\end{array}$ & $\begin{array}{l}\text { Accession } \\
\text { Number }\end{array}$ & $\begin{array}{l}\text { Query } \\
\text { Cover }\end{array}$ & $\begin{array}{l}\text { E- } \\
\text { Value }\end{array}$ & $\begin{array}{l}\text { Identity } \\
\text { percentage }\end{array}$ \\
\hline B.heterura & Brevitrygon heterura & MG792099 & $99 \%$ & 0.0 & $100.00 \%$ \\
D. zugei & Dasyatis zugei & EU398759 & $96 \%$ & 0.0 & $99.68 \%$ \\
Hemitrygon bennettii & Dasyatis bennettii & KF604910 & $99 \%$ & 0.0 & $99.85 \%$ \\
M. gerrardi & Himantura gerrardi & MH230945 & $100 \%$ & 0.0 & $99.69 \%$ \\
N. kuhlii & Neotrygon kuhlii & KU497951 & $100 \%$ & 0.0 & $99.85 \%$ \\
T. lymma & Taeniura lymma & KM 881715 & $100 \%$ & 0.0 & $99.39 \%$ \\
G. poecilura & Gymnura poecilura & EU398804 & $99 \%$ & 0.0 & $100.00 \%$ \\
Rhinoptera javanica & Rhinoptera javanica & JF494383 & $99 \%$ & 0.0 & $99.39 \%$ \\
Rhinobatos jimbaranensis & Rhinobatos jimbaranensis & EU398994 & $99 \%$ & 0.0 & $97.55 \%$ \\
\hline
\end{tabular}

Table 6. Nucleotide variant of COI gene fragment between same species

\begin{tabular}{lc}
\hline Sample $><$ Reference Sample & $\begin{array}{c}\text { Total number } \\
\text { of nucleotide } \\
\text { variant }\end{array}$ \\
\hline B. heterura $><$ MG792099 B. heterura & 0 \\
D. zugei $><$ EU398759 D. zugei & 2 \\
Hemitrygon bennettii $><$ KF604910 D. bennetti & 1 \\
M. gerrardi $><$ MH230945 Himantura gerrardi & 2 \\
N. kuhlii $><$ KU497951 N. kuhlii & 1 \\
T. lymma $><$ KM881715 T. lymma & 4 \\
G. poecilura $><$ EU398804 G. poecilura & 0 \\
Rhinoptera javanica $><$ MG792069 Rhinoptera & 4 \\
javanica & \\
Rhinobatos jimbaranensis $><$ EU398994 & 15 \\
Rhinobatos jimbaranensis & \\
\hline
\end{tabular}

Table 7. Batoidsconservation status by International Union for Conservation of Nature (IUCN) and trade status by Convention on International Trade in Endangered Species of Wild Fauna and Flora (CITES) in 2019.

\begin{tabular}{lll}
\hline Species & IUCN & CITES \\
\hline Rhinobatos jimbaranensis & Vulnerable & Not evaluated \\
G. poecilura & Near threatened & Not evaluated \\
Rhinoptera javanica & Vulnerable & Not evaluated \\
M. gerardi & Vulnerable & Not evaluated \\
T. lymma & Near threatened & Not evaluated \\
B. hetura & Not Evaluated & Not evaluated \\
D. zugei & Near threatened & Not evaluated \\
N. kuhlii & Data deficient (DD) & Not evaluated \\
Hemitrygon bennetti & Not Evaluated & Not evaluated \\
\hline
\end{tabular}


We successfully get $C O I$ gene fragment sequence from nine species of batoid which had been identified based on morphological features. The length of $\mathrm{COI}$ gene fragment after we conduct editing and combining primer forward and reverse sequence was $655 \mathrm{bp}$. By using this $655 \mathrm{bp}$ COI gene fragment we conduct similarity analysis using BLAST-N, the result of this analysis can be seen in Table. 4. The result of BLAST-N in all sample sequences above $97 \%$ in "Identity Percentage" value, the lowest was Rhinobatos jimbaranensis $(97.55 \%)$ and the highest was $B$. heterura and $G$. poecilura $(100.00 \%)$. After we aligning sequence sample and reference sequence, the length of $\mathrm{COI}$ fragment sequence which can be used in further analysis was 632 bp. Within same species, the range of genetic distance was $0.000-0.024$, while between different species was more than 0.1 . The lowest value of genetic distance (0.000) was found in G. heterura and G. poecilura, while the highest was in Rhinobatos jimbaranensis.

Our result in nucleotide diversity analysis showed that between same species, nine batoids species which we found, differ in 0-15 nucleotide (Table 6). The lowest number of variant nucleotides found in B. heterura and $G$. poecilura (0 nucleotide variant), while the highest (15 nucleotide variant) were found in Rhinobatos jimbaranensis. The phylogenetic tree showed that Dasyatidae was divided into two clades, one clade was consist of B. heterura, M. gerrardi, Rhinoptera javanica, and Rhinobatos jimbaranensis, and the other clade consist of D. zugei, Hemitrygon bennettii, N. kuhli, T, Lymma and G. poecilura (Figure 2). Even though Dyastidae divided into 2 clades, in each clade, every species of Dyastidae were forming smaller clade, separated from the other family. Maculabatis gerrardi were forming a small clade with $B$. heterura and $D$. zugei were forming a small clade with Hemitrygon bennettii, N. kuhli, and T. lymma.

Based on these results, we conclude that from 82 individuals we found in three landed sites (Tanjung Balai, Belawan, and Percut) were successfully identified belonged to nine species of batoid, both using morphological features identification and DNA identification using COI gene fragment. The mitochondrial cytochrome c oxidase subunit I (COI) gene identification could be used to evaluate batoid diversity, monitoring its conservation and fisheries management. This study about the use of DNA fragment to identifying batoid species needs further investigation by using another mitochondrial gene fragment to strengthening this finding. Furthermore, almost all batoid species which we found in these three landing sites its population is already.

\section{ACKNOWLEDGEMENTS}

This research was funded by Universitas Negeri Medan, Research Expertise Lecturer Group in 2019 budget year, No. 292D/UN33.8/PL/2019.

\section{REFERENCES}

Almeron-Souza F, Sperb C, Castilho CL, Figueiredo PICC, Gonçalves LT, Machado R, Oliveira LR, Valiati VH, Fagundes NJR. 2018. Molecular identification of shark meat from local markets on Southern Brazil based on DNA barcoding: evidence for mislabeling and trade of endangered species. Front Genet 9 (138): 1-12.

Altschul SF, Gish W, Miller W, Myers EW, Lipman DJ. 1990. Basic local alignment search tool. J Mol Biol. 215 (3): 403-410, 10.1016/S00222836(05)80360-2.

Blanco M, Perez-Martin RI, Sotelo CG. 2008. Identification of shark species in seafood products by forensically informative nucleotide sequencing (FINS). J Agric Food Chem 56: 9868-9874.

Byun SO, Fang Q, Zhou H, Hickford JG. 2009. An effective method for silver-staining DNA in large numbers of polyacrylamide gels. Anal Biochem. 385 (1): 174-5.

Cerutti-Pereyra F, Meekan MG, Wei NWV, O'Shea O, Bradshaw CJA, Austin, CM. 2012. Identification of Rays through DNA Barcoding: An Application for Ecologists. PLOS ONE 7( 6): 1-10.

Compagnon LJV. 1999. Batoid fishes. In: Carpenter KE (eds) The Living Marine Resources of the Western Central Pacific, Vol 3: Batoid Fishes, Chimaeras, and Bony Fishes Part 1 (Elopidae to Linophrynidae). FAO, Rome.

Dudgeon CL, Blower DC, Broderick D, Giles JL, Holmes BJ, Kashiwagi T, Krück NC, Morgan JAT, Tillett BJ, Ovenden JR. 2012. A review of the application of molecular genetics for fisheries management and conservation of sharks and rays. J Fish Biol 80: 1789-1843.

Fadhilah A, Susetya, IE, I Simeon BM. 2019. Elasmobranch catch composition of North Sumatra fishers. IOP Conference Series: Earth and Environmental Science. 260 (2109): 1-7.

Fahmi. 2010. Sharks and rays in Indonesia. Marine Research in Indonesia. 35(1): 43-54.

Felsenstein J. 1985. Confidence limits on phylogenies: An approach using the bootstrap. Evolution 39:783-791.

Hajibabaei M, Janzen DH, Burns JM, Hallwachs W, Hebert PDN. 2006. DNA barcodes distinguish species of tropical Lepidoptera. PNAS 103: 968-971.

Hall, T.A. 1999. BioEdit: a user-friendly biological sequence alignment editor and analysis program for Windows 95/98/NT. Nucl Acids Symp Ser 41: 95-98.

Hebert PDN, Cywniska A, Ball SL, DeWaard JR. 2003a. Biological identifications through DNA barcodes. Proceeding of the Royal Society B. 270: 313-321.

Hebert PDN, Ratnasingham S, deWaard JR. 2003b. Barcoding animal life: cytochrome c oxidase subunit 1 divergence among closely related species. Proceeding of the Royal Society of London B. 270:S96-S99.

Hoelzel A. 2001. Shark fishing in fin soup. Conservation Genetics. 2: 6972.

Kimura M. 1980. A simple method for estimating evolutionary rate of base substitutions through comparative studies of nucleotide sequences. Journal of Molecular Evolution 16:111-120.

Kinakesti SM, Wahyudewantoro G. 2017. Kajian jenis ikan Pari (Dasyatidae) di Indonesia. Fauna Indonesia. 16 (2): 17-25. [Indonesian]

Kumar S, Stecher G, Tamura K. 2016. MEGA7: Molecular evolutionary genetics analysis version 7.0 for bigger datasets. Mol Biol Evol 33 (7): 1870-1874.

Last PR, Naylor GJ, Manjaju-Matsumoto BM. 2016. A revised classification of the family Dasyatidae (Chondrichthyes: Myliobatiformes) based on new morphological and molecular insight. Zootaxa. 4193 (3): 345-368.

Last PR, Naylor GJP, Manjaji-Matsumoto BM. 2016. A revised classification of the Family Dasyatidae (Chondrichthyes: Myliobatiformes) based on new morphological and molecular insights. Zootaxa. 4139 (3): 345-368.

Last PR., White WT, Fahmi. 2006. Rhinobatos jimbaranensis and $R$. penggali, two new shovelnose rays (Batoidea: Rhinobatidae) from Eastern Indonesia. Cybium. 30 (3): 261-271.

Lim KC, Lim P-E, Chong VC, Loh K-H. 2015. Molecular and morphological analyses reveal phylogenetic relationships of stingrays focusing on the Family Dasyatidae (Myliobatiformes). PLoS One. 10 (4): e0120518. DOI: journal.pone.0120518.

Madduppa H, Ayuningtyas RU, Subhan B, Arafat D, Prehadi. 2018. Exploited but unevaluated: DNA barcoding reveals skates and 
stingrays (Chordata, Chondrichthyes) species landed in the Indonesian fish market. Ilmu Kelautan. 21 (1): 29-36.

McEachran JD, de Calvarho MR. 2002. Batoid fishes. In: Carpenter KE (eds) The Living Marine Resources of the Western Central Pacific, Vol 1: Introduction, Molluscs, Crustaceans, Hagfishes, Sharks, Batoid Fishes and Chimaeras. FAO, Rome.

Puillandre N, Strong EE, Bouchet P, Boissellier MC, Couloux A, et al. 2009. Identifying gastropod spawn from DNA barcodes: possible but not yet practicable. Mol Ecol Resour 9: 1311-1221.

Puteri D, Sitorus H, Muhtadi A. 2017. Fish diversity at mangrove ecosystem of Jaring Halus Village in Langkat Regency, North Sumatra. Jurnal Ilmu-Ilmu Perairan, Pesisir dan Perikanan. 6 (2): 145 152.

Rathipriya A, Marx KK, Jeyashakila R. 2019. Molecular identification and phylogenetic relationship of flying fishes of Tamil Nadu coast for fishery management purposes. Mitochondrial DNA Part A. 3 0(3): 500-510.

Riyanto B, Nurhayati T, Pujiastuti AD. 2013. Karakterisasi Glikosaminoglikan dari Tulang Rawan Ikan Pari Air Laut (Neotrygon kuhlii) dan Pari Air Tawar (Himantura signifer). Jurnal Pengolahan Hasil Perikanan Indonesia. 16 (3): 224- 232. [Indonesian]

Rodrigues Filho LFdaS, Feitosa LM, Silva Nunes JL, Onodera Palmeira AR, Martins APB, Giarrizzo T, Carvalho-Costa LF, Monteiro ILP, Gemaque R, Gomes F, Souza RFC, Sampaio I, Sales JBdeL. 2020. Molecular identification of ray species traded along the Brazilian Amazon coast. Fisheries Research. 223 (105407): 1-10.

Rodrigues-Filho LFdS, da Rocha TC, do Rego PS, Schneider H, Sampaio I, Vallinoto M. 2009. Identification and phylogenetic inferences on stocks of sharks affected by the fishing industry off the Northern coast of Brazil. Genetics and Molecular Biology. 32: 405-413.

Sadili D, Dharmadi, Fahmi, Sarmintohadi, Ramli I., Sudarsono. 2015. Rencana Aksi Nasional (RAN) Konservasi dan Pengelolaan Hiu dan Pari. Direktorat Konservasi dan Keanekaragaman Hayati Laut, Ditjen Pengelolaan Ruang Laut, Kementrian Kelautan dan Perikanan, Indonesia. www.kkp.go.id
Saitou N, Nei M. 1987. The neighbor-joining method: A new method for reconstructing phylogenetic trees. Mol Biol Evol 4: 406-425.

Siddappa CM, Saini M, Das A, Doreswamy R., Sharma, AK, Gupta, PK. 2013. Sequence characterization of mitochondrial $12 \mathrm{~S}$ rRNA Gene in Mouse Deer (Moschiola indica) for PCR-RFLP Based Species Identification. Molecular Biology International. 2013: 783925. DOI: $10.1155 / 2013 / 783925$.

Simpfendorfer C, Moore A., Elhassan I., Owfi F, Akhilesh KV. 2017. Brevitrygon walga. The IUCN Red List of Threatened Species 2017: e.T104176764A111015783. DOI: 10.2305/IUCN.UK.20172.RLTS.T104176764A111015783.en.

Subrata A, Wulandari D, Rizalinda. 2017. Inventarisasi Jenis Ikan Subkelas Elasmobranchii di Teluk Nuri Kecamatan Pulau Maya Kabupaten Kayong Utara. Protobiont. 6 (2): 45-49.

Tinti F, Ungaro N, Pasolini P, De Panfilis M, Garoia F, Guarniero I, Sabelli B, Marano G, Piccinetti C. 2003. Development of molecular and morphological markers to improve species-specific monitoring and systematics of Northeast Atlantic and Mediterranean skates (Rajiformes). J Exp Mar Biol Ecol 288: 149-165.

Ward RD, Zemlak TS, Innes BH, Last PR, Hebert PD. 2005. DNA barcoding Australia's fish species. Phil Trans R Soc B Biol Sci 360 (1462): 1847-1857.

Weigmann S. 2016. Annotated checklist of the living sharks, batoids and chimeras (Chondrichthyes) of the world, with a focus on biogeographical diversity. J Fish Biol 88: 837-1037.

White WT, Last PR, Stevens JD, Yearsley GK, Fahmi, Dharmadi. 2006. Economically important sharks and rays of Indonesia. Lamb Print, Perth, WA.

Wijayanti F, Abrari MP, Fitriana N. 2018. Keanekaragaman spesies dan status konservasi ikan pari di Tempat Pelelangan Ikan Muara Angke Jakarta Utara. Jurnal Biodjati 3 (1): 23-35. [Indonesian]

Zhang J, Hanner R. 2012. Molecular Approach to the Identification of fish in the South China Sea. Plos One 7 (2): e30621. DOI: 10.1371/journal.pone.0030621. 